\title{
Optimasi Parameter Input pada Artificial Neural Network untuk Meningkatkan Akurasi Prediksi Indeks Harga Saham
}

\author{
I. Wiseto P. Agung \\ Program Studi Teknik Informatika \\ Universitas Adhirajasa Reswara Sanjaya (ARS University) \\ Bandung, Indonesia \\ wiseto.agung @ ars.ac.id
}

\begin{abstract}
Stock trading is one of the businesses that has been done worldwide. In order to gain the maximum profit, accurate analysis is needed, so a trader can decide to buy and sell stock at the perfect time and price. Conventionally, two analyses are employed, namely fundamental and technical. Technical analysis is obtained based on historical data that is processed mathematically. Along with technology development, stock price analysis and prediction can be performed with the help of computational algorithms, such as machine learning. In this research, Artificial Neural Network simulations to produce accurate stock price predictions were carried out. Experiments are performed by using various input parameters, such as moving average filters, in order to produce the best accuracy. Simulations are completed with stock index datasets that represent three continents, i.e. NYA (America, USA), GDAXI (Europe, Germany), and JKSE (Asia, Indonesia). This work proposes a new method, which is the utilization of input parameters combinations of $\mathrm{C}, \mathrm{O}, \mathrm{L}, \mathrm{H}, \mathrm{MA}-5$ of $\mathrm{C}, \mathrm{MA}-5$ of $\mathrm{O}$, and the average of $\mathrm{O} \& \mathrm{C}$ prices. Furthermore, this proposed scheme is also compared to previous work done by Khorram et $a l$, where this new work shows more accurate results.
\end{abstract}

Keywords-artificial neural network, stock price prediction, moving average

Abstrak - Perdagangan saham merupakan salah satu jenis bisnis yang dilakukan di berbagai belahan dunia. Untuk mendapatkan profit yang maksimal, diperlukan analisa akurat sehingga seorang trader dapat memutuskan untuk membeli dan menjual saham pada waktu dan harga tepat. Secara konvensional, analisa yang digunakan adalah analisa fundamental dan analisa teknikal berbasis data historis yang diolah dengan pendekatan matematis. Dengan berkembangnya teknologi, maka analisa dan prediksi harga dapat dilakukan dengan dibantu algoritma komputasi, salah satunya adalah machine learning. Pada penelitian ini dilakukan simulasi pada Artificial Neural Network untuk mendapatkan hasil prediksi harga yang akurat. Eksperimen dilakukan dengan menggunakan berbagai parameter input termasuk dengan menggunakan filter moving average, untuk mendapatkan akurasi terbaik. Simulasi dilakukan dengan dataset indeks saham yang mewakili tiga benua yaitu NYA (Amerika, USA), GDAXI (Eropa, Jerman) dan JKSE (Asia, Indonesia). Penelitian ini mengusulkan metoda baru yaitu penggunaan input berupa kombinasi dari parameter harga $\mathrm{C}, \mathrm{O}, \mathrm{L}, \mathrm{H}, \mathrm{MA}-5$ dari $\mathrm{C}$, MA-5 dari $\mathrm{O}$, dan rata-rata $\mathrm{O} \& \mathrm{C}$. Selain itu, juga dibandingkan dengan metoda dari hasil penelitian yang telah dilakukan oleh Khorram et al, dan diperoleh bahwa metoda baru yang diusulkan ini memberikan hasil prediksi yang lebih akurat.

Kata Kunci-artificial neural network, prediksi harga saham, moving average

\section{PENDAHULUAN}

Memprediksi harga merupakan salah satu tantangan utama yang dihadapi para trader dan investor saham di dunia. Hal ini disebabkan karena semakin akurat prediksinya, maka keuntungan yang diperoleh akan semakin besar. Dalam berinvestasi saham, keuntungan yang tinggi bisa didapat dengan analisa yang akurat serta pemahaman yang dalam atas kondisi pasar dan saham perusahaan itu sendiri. Dengan demikian, sebelum para investor membeli dan menjual saham, dilakukan analisa yang mendalam. Dalam dunia perdagangan saham dikenal dua jenis analisa, yaitu fundamental dan teknikal.

Analisa fundamental bertujuan untuk mendapatkan nilai intrinsik dari saham suatu perusahaan. Sehingga penting bagi investor untuk mengevaluasi bisnis perusahaan tersebut seperti kinerja keuangan, operasional, bahkan kepemilikan dan manajemennya. Biasanya hal tersebut dapat dilihat melalui laporan keuangan dan laporan tahunan serta berita di media.

Sedangkan pada analisa teknikal, asesmen didasarkan pada data historis dari harga saham tersebut. Posisi jual dan beli saham dilakukan berdasarkan analisa atas perilaku harga saham di masa lalu, tren, serta kemungkinan pengulangan pola harga. Analisa teknikal ini biasanya ditampilkan dalam bentuk chart atau grafik yang menampilkan selain data histori harga, juga dengan beberapa indikator yang dihitung berdasarkan histori data tersebut, yang pada akhirnya dapat dilakukan prediksi harga [1].

Di sisi lain, dengan perkembangan ilmu komputer, maka analisa teknikal dan prediksi harga saham menjadi dipermudah dengan berbagai algoritma komputasi, salah satunya adalah dengan machine learning. Seperti yang disampaikan oleh [2], 
studi yang dilakukan oleh [3] menunjukkan bahwa penggunaan machine learning dalam area prediksi harga saham ini dapat meningkatkan efisiensi antara 60-86 persen dibandingkan dengan metode-metode sebelumnya.

Sudah cukup banyak dilakukan studi pemanfaatan machine learning untuk area investasi saham ini. Misalnya [2] melakukan studi komparasi teknik-teknik machine learning termasuk Neural Network, dan Support Vector Machines. Kemudian [4] menggunakan Artificial Neural Network untuk harga penutupan saham. Selain itu [5] menggunakan Recurrent Neural Network dan Discrete Wavelet Transform untuk memprediksi harga saham.

Paper ini melakukan studi pengaruh parameter input pada Neural Network dan untuk meningkatkan akurasi prediksi harga saham. Di sini dilakukan eksperimen kombinasi penggunaan parameter input Open, High, Low, Close, Vol, smoothing / filtering dengan berbagai perioda Moving Average serta turunannya. Dataset yang digunakan adalah index saham dari US, Eropa dan Indonesia yang diambil dari situs Yahoo Finance [6]. Evaluasi performansi dilakukan dengan mengukur Average Relative Error dari setiap kemungkinan yang ada sehingga bisa didapatkan hasil yang optimal. Sedangkan simulasinya dilakukan dengan RapidMiner [7].

Selanjutnya akan dibahas lebih detail tinjauan pustaka dari studi dan penelitian terkait yang pernah dilakukan oleh para peneliti sebelumnya. Kemudian dilanjutkan dengan penjelasan metode yang dilakukan penulis dalam penelitian ini. Setelah itu disampaikan pembahasan dari hasil penelitian, dan diakhiri dengan kesimpulan serta saran untuk penelitian berikutnya.

\section{TINJAUAN PUSTAKA}

\section{A. Analisa Teknikal pada Harga Saham}

Analisa yang didasarkan pada data historis dari saham untuk memperkirakan harga selanjutnya, maupun untuk menentukan waktu yang tepat untuk membeli atau menjual, dikategorikan sebagai analisa teknikal.

Fitur atau disebut juga indikator, yang memberikan banyak informasi tentang perubahan harga, merupakan hal penting untuk mendapatkan hasil analisa yang lebih akurat [8]. Fitur diperoleh dengan cara mengolah data-data historis dengan formula matematika tertentu.

Saat ini sudah cukup banyak fitur / indikator yang diberikan oleh para analis teknikal, misalnya Moving Average (MA), Moving Average Convergence and Divergence (MACD), Williams Overbought/Oversold Index (WR), Relative Strength Indeks (RSI), Rate of Change (ROC) [9].

Penelitian yang dilakukan oleh [10] menggunakan fiturfitur Relative Strength Index (RSI), Moving Average Convergence and Divergence (MACD), dan Williams \% $\mathrm{R}$, untuk menentukan saat yang tepat kapan beli dan jual, sehingga didapatkan keuntungan yang maksimal.

Penelitian ini akan fokus pada salah satu indikator yang penting dan banyak digunakan yaitu $n$-day Moving Average, yang didefinisikan sebagai berikut.

$$
M A(n)_{t}=\frac{p_{t-1}+\ldots+p_{t-n}}{n}
$$

dimana $p_{t-1}$ adalah harga Close sebelumnya.

Moving Average umumnya digunakan untuk meramalkan tren pada data finansial yang mempunyai noise. Penelitian [11] melakukan optimasi penghalusan (smoothing) Moving Average untuk meningkatkan akurasi analisa harga saham. Semakin besar periode window-nya $(n)$ akan semakin tinggi reduksi noise-nya dan semakin halus datanya.

\section{B. Aplikasi Machine Learning untuk Memprediksi Harga Saham}

Model-model time-series yang diturunkan dari teori ekonomi, merupakan kunci dasar untuk melakukan prediksi harga. Namun demikian, hipotesa-hipotesa tersebut tidak dapat diaplikasikan langsung untuk mengestimasi dan meramalkan harga kedepan. Hal ini disebabkan karena banyaknya faktor eksternal yang mempengaruhi. Oleh karena itu, perkembangan machine learning, termasuk artificial neural network dengan multi-layer, memberikan dukungan besar pada area ini [5].

Cukup banyak penelitian tentang penggunaan machine learning untuk memprediksi harga saham. Salah satunya adalah penelitian yang dilakukan oleh [2] yang mengevaluasi beberapa teknik machine learning dalam memprediksi harga. Algoritma yang dipakai adalah:

- Statistical-based Learners, meliputi: Logistic Regression (LR), Naive Bayes (NB), Linear Discriminant Analysis (LDA)

- Distance-based Learners, meliputi: K-Nearest Neighbour (K-NN), K-Star

- Tree-based learners, meliputi: C4.5, Classification and Regression Trees (CART), Random Forest (RF)

- $\quad$ Support Vector Machine (SVM)

- Artificial Neural Network (ANN)

Seperti yang disampaikan oleh [12], Artificial Neural Network (ANN) atau jaringan syaraf tiruan, adalah sistem yang terdiri dari beberapa elemen pemroses yang disebut neuron.

Multi-layer perceptron (MLP) merupakan turunan dari ANN yang mempunyai 3 layer yaitu input layer, output layer dan hidden layer, seperti ditunjukkan pada Gambar 1. Jumlah neuron pada input layer adalah sesuai dengan jumlah parameter input.

Neuron akan mengambil nilai-nilai dari parameter input kemudian menggabungkannya sesuai bobot yang telah ditentukan dan juga ada tambahan bias. Selanjutnya, dengan mengaplikasikan transfer function, akan dihasilkan nilai output.

Secara matematis, performansi dari neuron $\mathrm{P}$ dapat dituliskan sebagai berikut.

$$
\begin{gathered}
u_{P}=\sum_{i=1}^{n} w_{P i} x_{i} \\
y_{P}=\varphi\left(u_{P}+b_{P}\right)
\end{gathered}
$$


dimana $x_{i}, \ldots, x_{n}$ adalah parameter input; $w_{P 1}, \ldots w_{P n}$ adalah bobot koneksi (connection weight) dari neuron $\mathrm{P} ; u_{P}$ adalah input combiner; $b_{P}$ adalah bias; $\varphi$ adalah activation function; dan $y_{P}$ adalah output dari neuron.

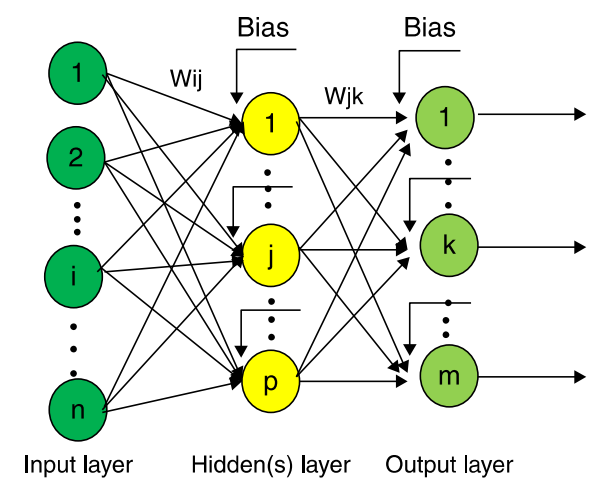

Gambar 1. Struktur Multi-layer feed forward neural network [12]

Penelitian yang dilakukan oleh Khorram et al [1] mencari parameter perioda Moving Average yang paling tepat untuk memprediksi harga dengan algoritma multilayer perceptron artificial neural network. Sebagai input dari ANN, adalah harga penutupan (Close) dan juga Moving Average dari harga tersebut dengan perioda 1 sampai dengan 200. Dari hasil studinya, disimpulkan bahwa performansi ANN terbaik diperoleh dengan menggunakan Moving Average dengan periode $5,25,48,50$ dan 89. Selain itu, [1] juga menyimpulkan bahwa Moving Average dengan periode yang rendah lebih cocok digunakan untuk memprediksi harga saham. Namun demikian, dari eksperimen yang penulis lakukan, dapat diperoleh performansi yang lebih baik dengan parameter input yang lain.

Pada penelitian yang penulis lakukan ini digunakan feed forward artificial neutral network yang di-training dengan algoritma back propagation, dengan menggunakan beberapa input harga serta berbagai periode Moving Average. Simulasi ANN dijalankan dengan komponen Neural Net pada RapidMiner [7].

\section{METODE PENELITIAN}

Pada penelitian ini, dilakukan eksperimen dengan langkahlangkah seperti ditunjukkan pada Gambar 2. Pertama, raw data yaitu data histori perdagangan saham yang akan dijadikan data set, diunduh dari situs Yahoo Finance [6], meliputi indeks saham Indonesia (JKSE), Amerika (NYA), Jerman (GDAXI). Data saham diambil selama 7 tahun (1773 hari perdagangan), mulai 2 Januari 2013 sampai dengan 30 Januari 2020. Data tersebut mempunyai beberapa parameter berupa harga saham saat pembukaan bursa (Open), harga tertinggi (High), harga terendah (Low), harga penutupan (Close), harga penutupan yang telah disesuikan (Adjusted Close) dan jumlah saham tersebut yang diperdagangkan pada hari tersebut (Volume).
Selanjutnya adalah pre-processing, dimana dilakukan filtering dengan menggunakan Moving Average (MA) terhadap parameter harga di atas. Perioda yang digunakan adalah MA-5, 10, 20, 25, 30, 40, 48, 50, 60, 70, 80, dan 89. Selain itu, juga dihitung nilai rata-rata Open dan Close dan juga rata-rata Low dan High, kemudian dilakukan filtering MA dengan berbagai periode.

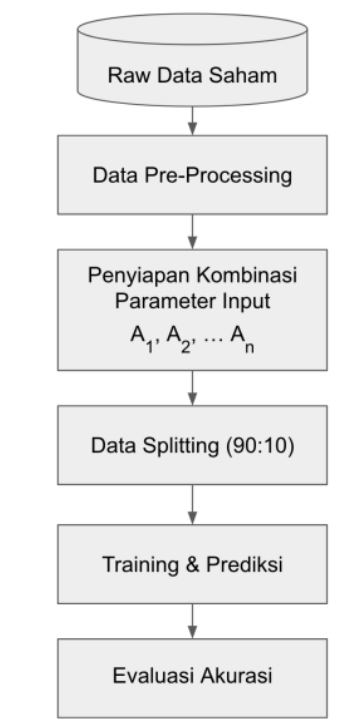

Gambar 2. Tahapan Penelitian

Langkah selanjutnya, disiapkan berbagai kombinasi parameter tersebut, yang akan menjadi input bagi neural network. Sehingga terdapat berbagai alternatif $\left(\mathrm{A}_{1} \ldots \mathrm{A}_{\mathrm{n}}\right)$ input. Pemilihan kombinasi dilakukan dengan logis dan terstruktur agar eksperimen efektif dari sisi waktu, yang akan dijelaskan lebih lanjut pada bagian hasil dan pembahasan.

Berikutnya, data-data tersebut dibagi dua menjadi data training dan data testing, dengan rasio $90 \%: 10 \%$. Kemudian dilakukan proses training dan prediksi dengan menggunakan algoritma Neural Network.

Langkah terakhir adalah evaluasi akurasi hasil prediksi, dengan menggunakan Average Relative Error (ARE), yaitu rata-rata dari deviasi absolut antara nilai prediksi $\left(v_{E}\right)$ dengan nilai sebenarnya $\left(v_{A}\right)$ dibagi dengan nilai sebenarnya [7].

$$
\mathrm{ARE}=\frac{1}{n} \sum_{t=1}^{n}\left|\frac{v_{A}-v_{E}}{v_{E}}\right| \cdot 100 \%
$$

Dari hasil evaluasi ini, dapat diidentifikasi alternatif kombinasi input yang memberikan akurasi tertinggi.

\section{HASIL DAN PEMBAHASAN}

Hasil penelitian diperoleh dengan menjalankan tahapan penelitian sesuai Gambar 2. Pada bab-IV ini, pertama akan dijelaskan lebih detail secara teknis apa yang dilakukan pada eksperimen. Kemudian, setelah itu akan disampaikan hasil dari simulasi dan pembahasannya. 
Mula-mula, data saham diunduh dari situs Yahoo Finance dengan menggunakan operator Read Yahoo Finance, yang ada di Operator Toolbox Extensions pada RapidMiner. Diperoleh 1773 baris data dan dibatasi bahwa kolom yang akan dipakai adalah Open, High, Low, Close. Sedangkan data Adj Close dan Vol, tidak digunakan pada penelitian ini.

Selanjutnya dilakukan proses perhitungan rata-rata Open $(O)$, Close $(C)$ dan juga rata-rata Low $(L)$, High $(H)$. Langkah berikutnya adalah menghitung moving average dengan bantuan operator Moving Average Filter. Perioda MA yang digunakan adalah 5,10, 20, 25, 30, 40, 48, 50, 60, 70, 80, 89.

Perlu diketahui bahwa perhitungan rata-rata $\mathrm{O}, \mathrm{C}$ dan juga L, H serta pemilihan periode MA tersebut bertujuan untuk menguji hasil temuan penelitian yang dilakukan oleh [1] dan juga mengupayakan peningkatan performansi akurasi prediksi, melalui berbagai kombinasi input ANN.

Pada tahap data pre-processing tersebut, setelah dilakukan perhitungan moving average, baris-baris data yang mempunyai nilai tidak relevan, dihilangkan. Sehingga diperoleh 1680 baris data dengan 132 attributes.

Selanjutnya data-data tersebut dimasukkan sebagai input dari ANN dengan berbagai kombinasi untuk mencari performansi terbaik yang diukur dengan kesalahan atau error terkecil. Dilakukan eksperimen mulai dari satu input yaitu $\mathrm{C}$ saja; kemudian dua input $\mathrm{CO}, \mathrm{CL}, \mathrm{CH}$; dan berbagai kemungkinan input lainnya. Salah satu contoh kombinasi input (C, O, L, H, C5, O5, AvgOC, AvHL) ditunjukkan pada Gambar 3. Pada eksperimen ini digunakan operator Neural Net dengan 2 hidden layers dan 200 training cycles, sedangkan parameter lainnya dibiarkan sesuai default.

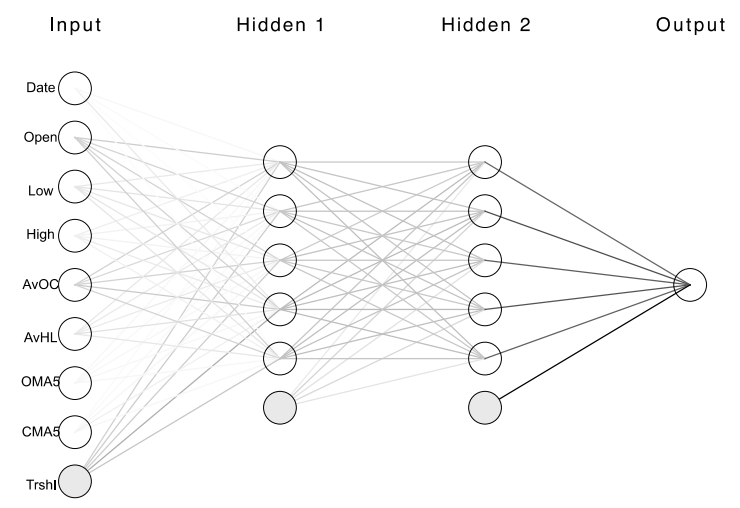

Gambar 3. ANN dengan Beberapa Input dan Dua Hidden Layer

Selanjutnya, data dibagi dua menjadi data training $(90 \%)$ dan data testing $(10 \%)$, dengan melalui operator Split Data. Proses training akan menghasilkan model yang digunakan untuk memprediksi. Contoh hasil prediksi untuk indeks saham JKSE (warna hijau) dan data sebenarnya (warna biru), ditunjukkan pada Gambar 4 di bawah ini. Dari contoh tersebut dapat dilihat bahwa hasil prediksi mendekati nilai sebenarnya.

Tahap terakhir adalah melakukan evaluasi performansi akurasi hasil prediksi, dengan melakukan pengukuran Average Relative Error, ARE, melalui operator Performance pada

\section{Rapidminer.}

Berikut ini akan disampaikan hasil pengukuran yang khusus mengevaluasi performansi dari penggunaan periode tertentu pada moving average yang diaplikasikan pada parameter input $\mathrm{O}, \mathrm{H}, \mathrm{L}$, dan $\mathrm{C}$ secara independen. Jadi untuk parameter $\mathrm{O}$, mula-mula sebagai input adalah $\mathrm{C}$ saja; kemudian $\mathrm{C}$ dan O; C dan MA-5 dari O; C dan MA-10 dari O; dan seterusnya sampai C dan MA-89 dari O. Hal yang sama dilakukan untuk $\mathrm{H}$, L, dan $\mathrm{C}$.

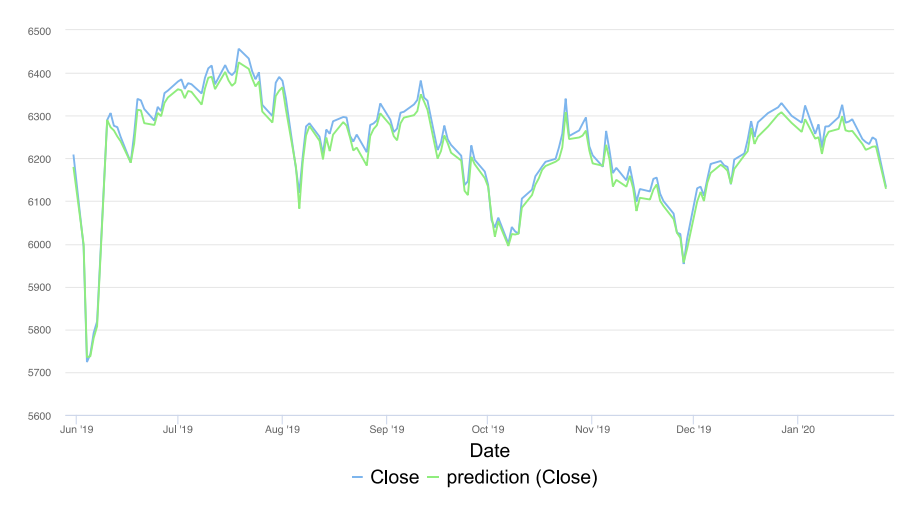

Gambar 4. Hasil Prediksi JKSE dan Data Sebenarnya

Hasil simulasi di atas untuk ketiga indeks JKSE, NYA, dan GDAXI, disampaikan pada Gambar 5, 6, dan 7 sebagai berikut.

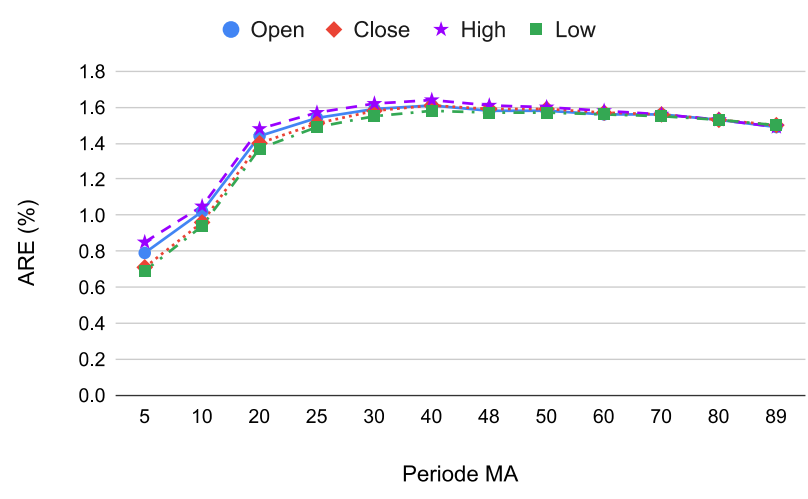

Gambar 5. Relative Error berbagai periode MA pada indeks JKSE

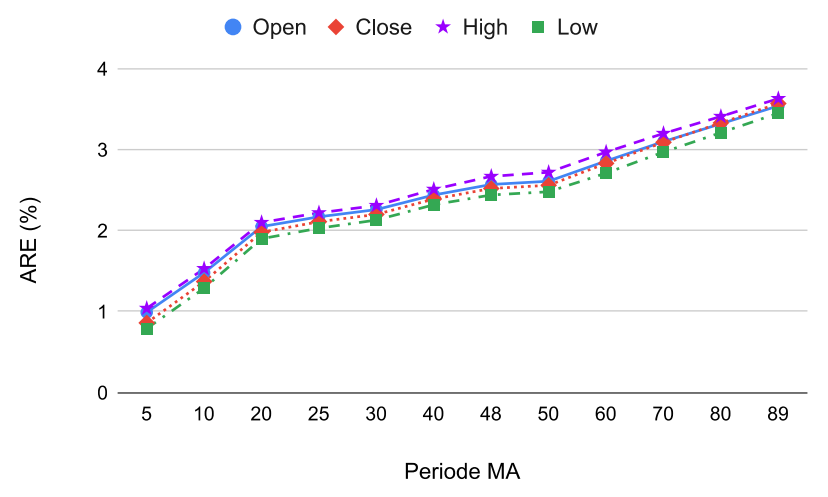


Gambar 6. Relative Error berbagai periode MA pada indeks NYA

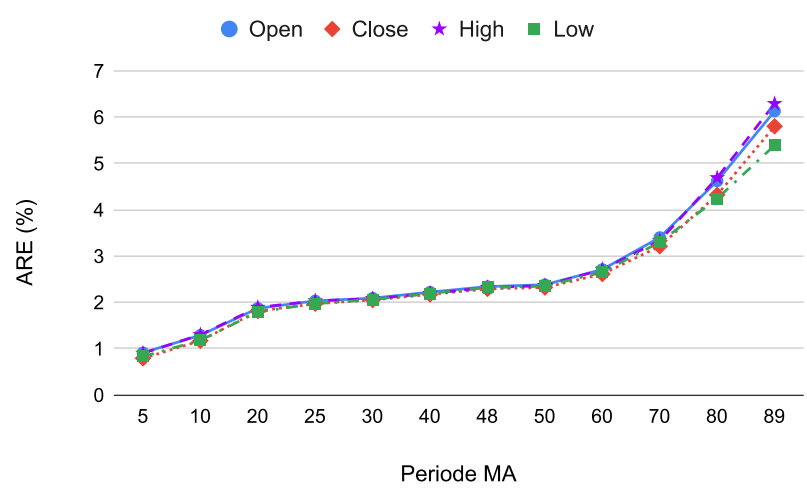

Gambar 7. Relative Error berbagai periode MA pada indeks GDAXI

Dari ketiga gambar tersebut, dapat dilihat bahwa secara umum semakin tinggi periode MA maka error akan semakin besar. Sedikit perkecualian untuk JKSE, mulai MA-50 ke atas error sedikit mengecil kembali. Dengan kata lain, dapat disampaikan bahwa hasil prediksi semakin akurat bila input menggunakan MA dengan periode yang rendah, yaitu 5.

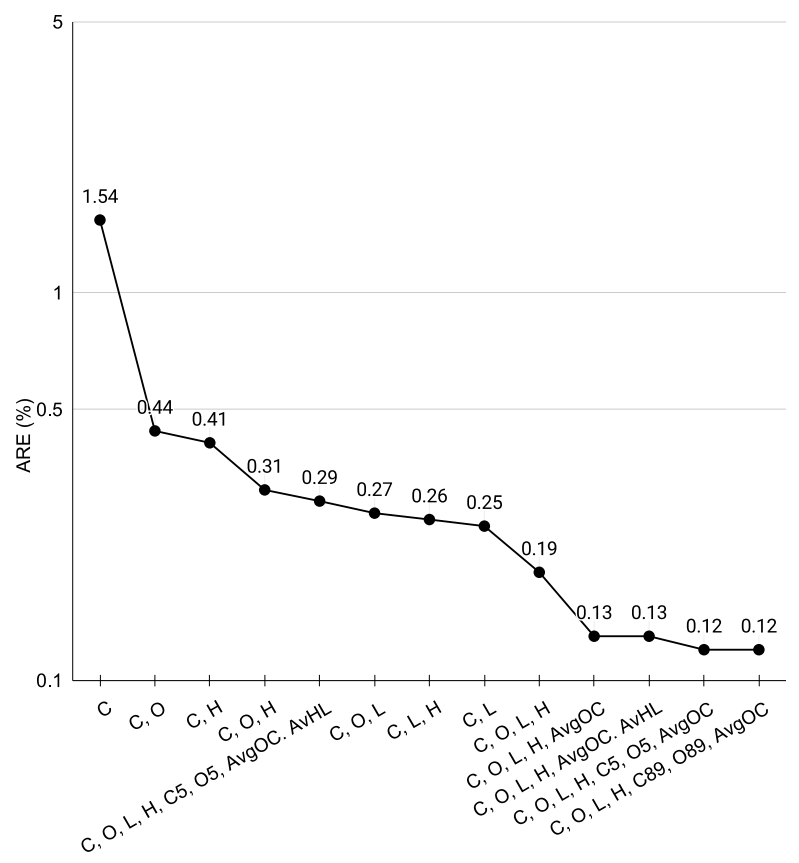

Parameter Input

Gambar 8. Relative Error berbagai Kombinasi Input pada indeks JKSE

Selanjutnya akan disampaikan hasil pengukuran dari simulasi yang mengkombinasikan berbagai input, termasuk rata-rata $\mathrm{O}$ dan $\mathrm{C}$, rata-rata $\mathrm{H}$ dan $\mathrm{L}$, serta moving average dari parameter O, H, L, C. Dari sekian banyak kombinasi, berikut ini hanya disampaikan beberapa hasil yang signifikan dan menggambarkan perbedaan yang jelas, pada Gambar 8, 9, dan 10.
Dari Gambar tersebut, dapat dilihat bahwa hasil prediksi terbaik, dengan error terkecil, diperoleh apabila digunakan tujuh parameter input yaitu $\mathrm{C}, \mathrm{O}, \mathrm{L}, \mathrm{H}, \mathrm{MA}-5$ dari C, MA-5 dari $\mathrm{O}$, dan rata-rata $\mathrm{O} \& \mathrm{C}$.

Sedikit catatan khususnya untuk JKSE, selain 7 parameter di atas, akurasi yang sama juga dapat diperoleh dengan kombinasi parameter C, O, L, H, MA-89 dari C, MA-89 dari $\mathrm{O}$, dan rata-rata $\mathrm{O} \& \mathrm{C}$.

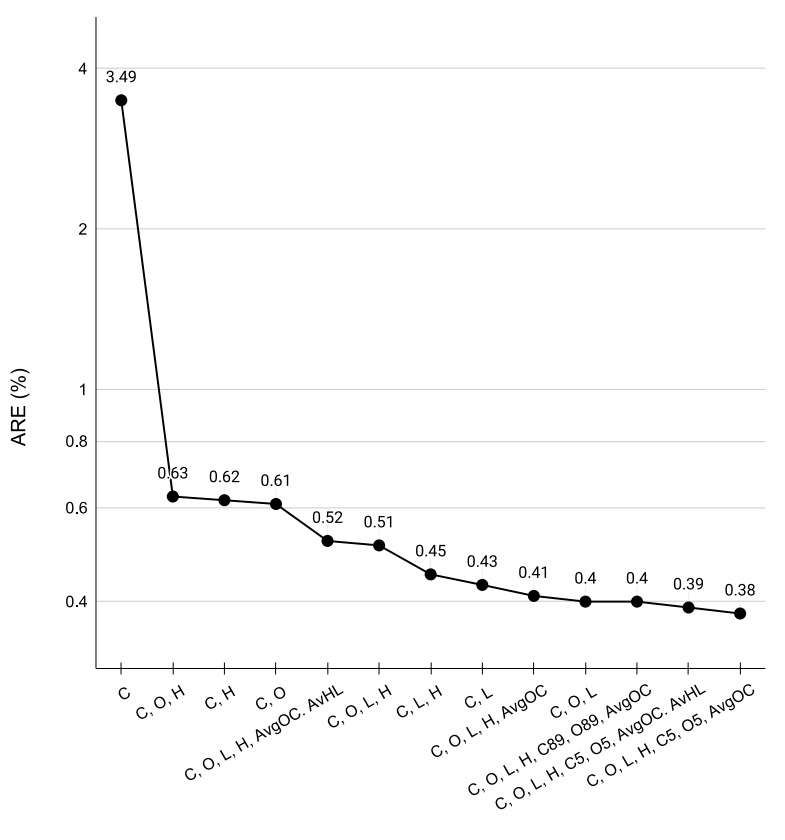

Parameter Input

Gambar 9. Relative Error berbagai Kombinasi Input pada indeks NYA

Dan akhirnya, akan disampaikan ringkasan perbandingan hasil penelitian ini dengan penelitian sebelumnya yang dilakukan oleh [1] pada Table I di bawah ini.

TABLE I. Perbandingan Dengan Peneliti Sebelumnya

\begin{tabular}{|l|l|c|}
\hline Metoda & \multicolumn{1}{|c|}{$\begin{array}{c}\text { Parameter Input } \\
\text { Terbaik }\end{array}$} & Hasil Eksperimen Penulis \\
\hline $\begin{array}{l}\text { Khorram } \\
\text { et al }[1]\end{array}$ & $\begin{array}{l}\text { MA-5, 25, 48, 50, dan } \\
89\end{array}$ & $\begin{array}{c}\text { Semakin kecil perioda maka } \\
\text { semakin tinggi akurasi prediksi }\end{array}$ \\
\hline $\begin{array}{l}\text { Usulan } \\
\text { Penulis }\end{array}$ & $\begin{array}{l}\text { Kombinasi C, O, L, H, } \\
\text { Mari O, dan C, MA-5 } \\
\text { \& C }\end{array}$ & $\begin{array}{c}\text { Kombinasi 7 parameter input ini } \\
\text { menghasilkan akurasi prediksi } \\
\text { yang lebih baik }\end{array}$ \\
\hline
\end{tabular}

Tabel di atas menggambarkan bahwa penulis melakukan eksperimen dengan menguji parameter input yang diusulkan oleh [1], dimana diperoleh gambaran yang sejenis bahwa semakin kecil perioda maka semakin tinggi akurasi prediksi. Namun demikian hal tersebut tidak spesifik hanya untuk MA$5,25,48,50$, dan 89 saja; karena hasil tersebut juga berlaku untuk MA-10, 20, 25, 30, 40, 48, 50, 60, 70, 80, dan 89 yang disimulasikan.

Lebih jauh, dari simulasi yang dilakukan, penulis juga mendapatkan bahwa kombinasi parameter input $\mathrm{C}, \mathrm{O}, \mathrm{L}, \mathrm{H}$, 
MA-5 dari C, MA-5 dari O, dan rata-rata O \& $\mathrm{C}$ menghasilkan hasil prediksi yang lebih akurat. Sebagai contoh, untuk indeks saham GDAXI, akurasi terbaik metoda [1] adalah dengan nilai Average Relative Error $0.79 \%$ (dengan input MA-5 dari C), sedangkan dengan menggunakan metoda yang penulis usulkan, diperoleh error yang lebih kecil, yaitu sebesar $0.21 \%$.

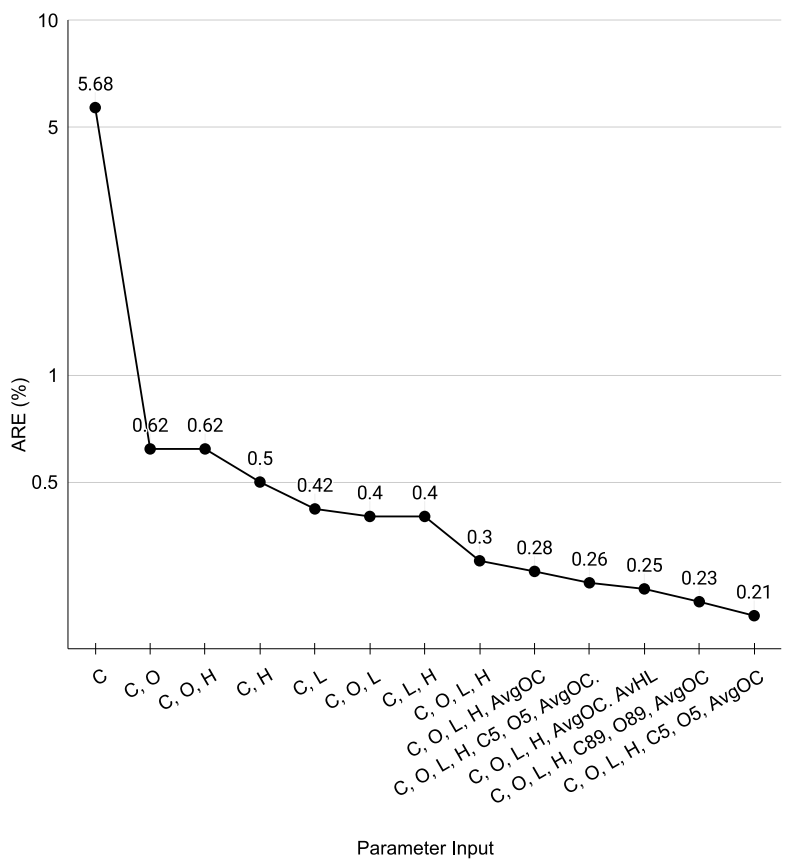

Gambar 10. Relative Error berbagai Kombinasi Input pada GDAXI

\section{KESIMPULAN}

Dari hasil pembahasan di atas dapat disampaikan bahwa penelitian dengan menggunakan algoritma Artificial Neural Network yang dilakukan untuk meningkatkan akurasi prediksi ini menghasilkan beberapa hal sebagai berikut. Pertama adalah bahwa akurasi prediksi ANN sangat tergantung dari input yang dimasukkan. Kemudian, untuk akurasi prediksi indeks harga saham ini, parameter harga $\mathrm{C}, \mathrm{O}, \mathrm{L}, \mathrm{H}$ berperan penting. Penelitian ini juga mengamati tingkat akurasi dari prediksi. Apabila ditambahkan input filtering moving average dengan berbagai perioda untuk parameter tersebut di atas, diperoleh hasil bahwa semakin rendah perioda MA, akan memberikan error yang lebih kecil atau akurasi prediksi yang lebih baik.
Dan paper ini juga mengusulkan kombinasi input parameter yang dapat menghasilkan akurasi tertinggi yaitu kombinasi dari parameter input $\mathrm{C}, \mathrm{O}, \mathrm{L}, \mathrm{H}, \mathrm{MA}-5$ dari C, MA-5 dari O, dan rata-rata $\mathrm{O} \& \mathrm{C}$. Mengingat pada penelitian ini digunakan Simple Moving Average (SMA), maka pada penelitian selanjutnya dapat fokus pada jenis moving average lainnya. Selain itu, penelitian berikutnya juga dapat menguji temuan saat ini untuk berbagai algoritma machine learning lainnya, untuk mendapatkan performansi yang lebih baik.

\section{REFERENCES}

[1] M. Khorram, M. Sheshmani, "What Period of Time is better to Use for Moving Average to Predict Stock Price in Tehran Stock Exchange?", Indian Journal of Science and Technology, Vol 8 (27) October 2015

[2] A. Syukur, D. Istiawan, "Prediction of LQ45 Index in Indonesia Stock Exchange: A Comparative Study of Machine Learning Techniques", International Journal of Intelligent Engineering and Systems, Vol.14, No.1, 2021

[3] L. Li, Y. Wu, Y. Ou, Q. Li, Y. Zhou and D. Chen, "Research on Machine Learning Algorithms and Feature Extraction For Time Series," 2017 IEEE 28th Annual International Symposium on Personal, Indoor, and Mobile Radio Communications (PIMRC), 2017, pp. 1-5.

[4] M. Vijk, D. Chandola, V.A. Tikkiwal, A.Kumar, "Stock Closing Price Prediction using Machine Learning Techniques", Procedia Computer Science 167, 2020, pp. 599-606

[5] M. Jarrah, N. Salim, "A Recurrent Neural Network and a Discrete Wavelet Transform to Predict the Saudi Stock Price Trends", International Journal of Advanced Computer Science and Applications, Vol. 10, No. 4, 2019

[6] Yahoo Finance, https://finance.yahoo.com/ diakses 17 Januari 2021.

[7] RapidMiner, "RapidMiner Studio Manual", 2014, https://docs.rapidminer.com/

[8] Z. Berradi, M. Lazaar, "Integration of Principal Component Analysis and Recurrent NeuralNetwork to Forecast the Stock Price of Casablanca Stock Exchange", Procedia Computer Science 148 (2019) pp. 55-61

[9] H. Zhang, "The Forecasting Model of Stock Price Based on PCA and BP Neural Network", Journal of Financial Risk Management, 2018, 7, pp. 369-385

[10] O.B. Sezer, A.M. Ozbayoglu, E. Dogdu, "An Artificial Neural Networkbased Stock Trading System Using Technical Analysis and Big Data Framework", ACM SE '17: Proceedings of the SouthEast Conference, April 2017, pp. 223-226

[11] A. Raudys, Z. Pabarskaite, "Optimising The Smoothness and Accuracy of Moving Average for Stock Price Data", Technological and Economic Development of Economy, 2018, 24(3): pp. 984-1003

[12] A.H. Moghaddam, M.H. Moghaddam, M. Esfandyari, "Stock market index prediction using artificial neural network", Journal of Economics, Finance and Administrative Science 21, 2016, pp. 89-93. 